\title{
TEACHING SCIENCE USING ENGLISH DONE BY PRIMARY SCHOOL TEACHERS IN MALANG
}

\author{
Pritha Anggiarima \\ Universitas Negeri Malang \\ angieprithamcfly@gmail.com
}

\begin{abstract}
English as a Medium of Instruction (EMI) is relied by many teachers to achieve bilingual education goals. The purpose of teaching any other subjects in English is to prepare the students to learn from the firsthand sourcewhen later they pursue higher education. However, there are some challenges when it comes to the practice in young learners. This paper discusses the strategies and problems faced by science teachers in bilingual primary schools in Malang. A questionnaire was distributed to all science teachers who were delivering their lesson in English to determine their educational background, strategies, experiences, and obstacles when they were teaching Science using English. The researcher also asked them about the textbook they used and the students' average score in Science. As a result, it can be analyzed how successful the teaching of Science using English in bilingual primary schools in Malang.
\end{abstract}

Keywords: Teaching Science, EMI, Bilingual primary school

\section{INTRODUCTION}

The increasing number of bilingual school makes people aware of the importance of English as a Medium of Instruction (EMI). In this era, more parents send their children to International Schools to prepare them for the increasingly globalized era. Studying in International or Bilingual school means some of the lessons are delivered in English, commonly Math, Science, and local contents such as Health Education.

In Indonesia, bilingual education is done in both international schools which are established for expatriates residing in Indonesia, and in national plus schools or schools called SPK (Satuan Pendidikan Kerjasama-Joint Education Unit?). SPK schools are cooperating with international education institutions such as Cambridge, International Baccalaureate, or High School Certificate. Therefore, the textbooks used for delivering the lessons are the ones issued by those institutions, and of course they are written in English.

To avoid misunderstanding, the following is explanation of the difference between SPK School and International school. Based on the regulation of Minister of Education and Culture No. 31 of 2014, it is explained that international schools are only for children of foreign diplomatic personnel or schools for one particular nationality. Meanwhile, SPK schools must also include three compulsory local curriculum subjects, namely Citizenship, Indonesian and Religion, into their curriculum to be given to Indonesian students. Foreign students studying in SPK schools must also be given 
Indonesian subjects. In addition, Indonesian students from SPK schools were also asked to take the National Examination in addition to the international based examinations.

Based on the regulation of the Minister of Education and Culture No. 31 of 2014 concerning in the Cooperation and the Implementation and Management of Education by Foreign Education Institutions with Indonesian Educational Institutions, schools that adopt a foreign curriculum must be in the form of a cooperative education unit. The Cooperation Education Unit (SPK) is an adjustment from an international school that is organized or managed on the basis of implementation cooperation, or management between foreign educational institutions and Indonesian educational institutions on formal or non-formal channels. Even though those schools adapt international curriculum and use imported books, those schools are still obligated to conduct examination similar to other schools in Indonesia such as computer-based national exam (UNBK). Based on the information provided in Malang Education Authorities office, SPK schools in Malang are: Bina Bangsa School, PJ Global School, Wesley International School, Charis National Academy, My Little Island, Indonesia Interactive Standard School (IISS), UM Laboratory School, Brawijaya Smart School, and Baitul Makmur Sawojajar School. Even though there are several SPK schools in Malang, not all teachers who are teaching in those schools were participating in this study.

There is a reason behind conducting this study. The researcher herself was once a teacher in an international primary school. She has observed her fellow teachers who are teaching science, some of them found difficulty in teaching science using English, therefore she wants to explore more on why they have such problem. She expects that by determining the problems they face and the strategy they use on teaching science using English, a way out to solve the difficulty could be discovered.

This paper focuses on how Science subject is delivered in English by science teachers in various primary schools in Malang. The purpose of writing this paper is to determine the strategies done by the science teachers in delivering the lesson, the obstacles they found on learning science using English and to teach them, the students' understanding to science materials delivered in English and their learning achievement.

\section{METHODS}

This research employs survey method. A survey means to answer questions that have been raised, to solve problems that have been posed or observed, to assess needs and set goals, to determine whether or not specificobjectives have been met, to establish baselines against which future comparisonscan be made, to analyze trends across time, and generally, to describe what exists, inwhat amount, and in what context. (Isaac \& Michael, 1997). The researcher constructed twelve questions written in Indonesian to be sent to Science Teachers who were teaching science in International/Bilingual primary 
schoosl in Malang. The questionnaire was administered through Google Form and was spread to primary school teachers. Below is the questionnaire for the teachers.

1. Mention the University where you graduated from and the major you were taking.

2. How many years have you been teaching science?

3. Back in your college years, did you join a class prepared to teach in bilingual/international school?

4. If the answer of number 3 is no, how do you learn science materials written in English?

5. What obstacles did you have when learning science materials written in English?

6. What obstacle did you have in the class when delivering science lesson in English to the students?

7. Do you also use English in your daily life?

8. What difficulties dostudents have when learning science in English?

9. What strategies do you usein helping students to understand science in English?

10. Mention all the textbooks you have used on teaching science using English.

11. Among all those books you have used, which one do you like the most? Give the reason why?

12. How successful are your students on learning Science using English?

The researcher spent one month to spread the questionnaire to science teachers, unfortunately she only gained seven responses.

\section{FINDINGS AND DISCUSSION}

For question number one, two respondents graduated from Physics Education, two respondents graduated from Science Education, one respondent from Biology Education, one respondent from Japanese Education, and one respondent from English Department UM.

For question number two, two teachers answered one year, one teacher answered two years, one teacher answered three years, two teachers have taught for four years, and one teacher has taught for eight years.

For question number three, none of them attended a program arranged for teaching science in bilingual program. Therefore, on answering question number four, there are these strategies on learning the science materials written in English: translating 
manually, learning by oneself, summarizing the materials and asking the seniors, and learning the textbook.

On answering question number five, here are some difficulties the teachers have: Understanding the vocabularies and terminologies, how to explain the terminologies to the students, and determining the proper media to teach the materials. Many of those teachers stated that there are many definition differences between scientific English and general English, such as the term ' gaya' which means 'force' in scientific English and it may mean 'style' in General English.

On answering the question number six, these are the obstacles they found: how to make the vocabularies be understood well by the students, pronunciation awareness, making them understanding the concept, and the students' educational background. What is meant by educational background here means there are some students who have been accustomed to speak English since they were in kindergarten. Some students happen to have expatriate parents, and some have experienced living in foreign country for years. Explaining Science in Indonesian alone has taken efforts, moreover, if it is delivered in English, as the teacher him/herself does not feel confident with his/her English ability.

On answering the question number seven, one teacher answered "always" on English-speaking frequency, three teachers answering "often", and three teachers answering "seldom".

For question number eight, the most problems that the students encounter when learning Science in English are on understanding the terminologies. The other problems are understanding the concept of science itself.

To overcome the problems, here are the strategies done by the teachers: Creating mini dictionary and vocabulary list, giving worksheets, illustrating the difficult words in the real life, using flash cards, using songs, and giving picture aid.

There are several textbooks used for teaching science using English, they are: Esis, Science Alive, Big Science, Collins International Primary Science, Gasing, Erlangga Bilingual, My Pals are Here, and English Chest. There are several reasons why the teachers preferred those books. Esis is preferred because of its simple language and good supporting illustration. Science Alive has simple language and good teaching sequence. Cambridge has simple language and ispractical enough to make the students understand the concept of the experiments, and not only memorizing the theory. Meanwhile, My Pals are Here is preferred because of its simple language.

However, albeit having those obstacles on teaching, the teachers considered the students achieved quite good results on their learning. Most of the respondents stated 
that the students achieved beyond the minimum standard, or beyond 75. The students who got below 75 are those whose English proficiency was not that good.

According to Haynes (2018), there are several problems of English language learners (ELL) on learning Science using English,. First is that the vocabulary of science presents a huge difficulty. There are a special set of terms for the student to learn. Even simple words that the student may know, could have another meaning in science; Material is covered very fast; Directions are often multistep and difficult; There are too many concepts explained on each page of a science text; Cooperative learning may not fit in with students experiences in learning; Visuals may be confusing and difficult to understand; Sentence structure is complex and the assive voice is used in textbooks; What was taught in class does not always match the assessment; ELLs are not used to science labs or equipment; Students lack background in scientific method, and there is no standard form of delivery of information.

Buck (2000) states that there are some strategies in delivering Science lessons in English to Primary School students, and these have been practiced by the respondents based on their statements in the questionnaire answers. Teaching science using English should include visuals that illustrate the subject matter. For example, if the teacher is describing various stages of a plant's life cycle, they can use pictures to illustrate the seed, the seed developing a root, stem and leaf formation, flower development, and the new seed. These pictures directly relate to the discussion and can be sequenced in a logical order. Other basic strategies might be: Using the board to draw pictures to support an oral discussion, as well as writing new words such as root and stem; giving step by step direction one at a time when having an actual observation of an object, the students are asked to write down how an object is similar to the others; preparing list of terms on a large paper, and those are of familiar words of the unit. Students are encouraged to check this list everytime they forgot the terms; rephrasing unclear statements in simpler statements, relate them to the students' real life. Such as, "There are plant parts that we cannot see because they are buried in the dirt." "These plant parts can grow new parts that come above the dirt." "We can then see these new parts.");

Other strategies include giving summaries of what has been taught without waiting to review until one chapter is finished and an exam is to be given the next day. Review the concept with the students and check the understanding; If possible, an assistance of a native speaker and a nonnative English speaker would do; giving various instructional delivery (using picture books, hands-on activities, demonstrations, and group discussions.); Encourage parent participation in classroom activities. The researcher herself has experienced having students whose parents are proficient in English and have experienced living abroad, therefore collaborating with parents to give English inputs to the students during science lesson will do good on them; involving students in peer instruction and connect to students' out-of-school experiences that relates with the 
chapter they are dealing with, Hands-on science activities allow students to follow along without having to solely depend on the spoken word. However, make sure the activity directly relates to the concept being taught, and be aware of possible misconceptions that may occur to students who are relying on the activity to illustrate the concept.

There are some learning strategies proposed by Buck (2000) which can be adapted on teaching science using English to primary school students. Teachers should consider the prior knowledge schemata, encouraging the students to generate questions, doing scaffolding by giving the students complete examples and demonstration. If they are well equipped with hands-on experiences, they will need less support; summarizing is also needed. Once the teacher has completed a concept, the students should summarize what they learned. This allows them to work for understanding throughout the unit(Chamot, 1999).

In fact, some universities in Malang has offered B.A. Program in Science Teaching. They offer some courses to prepare their graduates to teach Science using English. For example, B.A. Program in Science Teaching (S1 Pendidikan IPA) in Universitas Negeri Malang offers a course named English for Science Teaching which is targeted to analyze and translate English texts relating to science, and to equip them with sufficient vocabulary bank on science field as a basis to learn more about science and to teach it later. Teachers who graduate from this program can share their knowledge to the colleagues who did not take this course when they were in college.

Also, some of the Bilingual/international schools usually have a cooperation with foreign book publishers. The researcher herself she was several times sent to trainings and seminars held by some book publishers. The training was held once in a semester. Usually, the book publishers invite experts and also the textbook authors. Not only was a plenary talk on teaching science using English given, but also small-group sessions to discuss more about teaching science using English and a small practice session to train some skills in teaching English using Science. After the training, the teacher can share the training materials to other science teachers.

\section{CONCLUSION AND SUGGESTIONS}

It is concluded that not many teachers still have obstacles in teaching science using English in primary school, and it is caused by the teachers' English proficiency itself. However, even though they are not graduated from the program that prepared them to teach in bilingual school, this can be solved. To anticipate that, it is suggested that the school should provide regular trainings to strengthen the science teachers' skills either in English terminologies mastery and also the science knowledge itself. Besides that, those aforementioned strategies mentioned by Buck can also be practiced on teaching Science using English 
For the students, besides being aided by a fully-illustrated and children-friendly textbooks on Science written in English, they are also encouraged to explore more on their surroundings because science deals with their daily life. They should be active and cooperative on doing the experiments so that hands-on experiences will help them understand science more.

\section{REFERENCES}

Buck, Gayle A., "Teaching Science to English-as-Second-Language Learners: Teaching, learning, and assessment strategies for elementary ESL students" (2000). Faculty Publications: Department of Teaching, Learning and Teacher Education.

Chamot. A.U. and O’Malley, J.M. (1994). The CALLA Handbook: Implementing the Cognitive Academic Language Learning Approach. New York: AddisonWesley

Dearden, Julie (2014). English as a medium of instruction - a growing global phenomenon. The British Council

Haagen-Schützenhöfer, Claudia \& Mathelitsch, Leopold. (2003). English as a Medium of Instruction in Teaching Physics. 79-88.

Haynes, J. (2018). Challenges for ELLs in Content Area Learning. Teaching Community (Online), http://teaching.monster.com/benefits/articles/6307challenges-for-ells-in-content-area-learning, accessed on 10 Nov 2018.

Hernandez-Nanclares (2015), English as a medium of instruction: evidence for language and content targets in bilingual education in economics. International Journal of Bilingual Education and

Isaac, S., \& Michael, W. B. (1997). Handbook in research and evaluation: A collection of principles, methods, and strategies useful in the planning, design, and evaluation of studies in education and the behavioral sciences. (3rd Ed.). San Diego: Educational and Industrial Testing Services.

Ministry of Education and Culture of Indonesia (2014). The regulation of Minister of Education and Culture No. 31 of 2014. (Online) https://kelembagaan.ristekdikti.go.id/wp-

content/uploads/2016/11/permen_tahun2014_nomor031-1.pdf, accessed on 24 June 2019. 